\title{
Customer Perceived Value, Satisfaction, and Loyalty: The Role of Switching Costs
}

\author{
Zhilin Yang \\ City University of Hong Kong \\ Robin T. Peterson \\ New Mexico State University
}

\begin{abstract}
It is a marketplace reality that marketing managers sometimes inflict switching costs on their customers, to inhibit them from defecting to new suppliers. In a competitive setting, such as the Internet market, where competition may be only one click away, has the potential of switching costs as an exit barrier and a binding ingredient of customer loyalty become altered? To address that issue, this article examines the moderating effects of switching costs on customer loyalty through both satisfaction and perceived-value measures. The results, evoked from a Web-based survey of online service users, indicate that companies that strive for customer loyalty should focus primarily on satisfaction and perceived value. The moderating effects of switching costs on the association of customer loyalty and customer satisfaction and perceived value are significant only when the level of customer satisfaction or perceived value is above average. In light of the major findings, the article sets forth strategic implications for customer loyalty in the setting of electronic commerce. (C) 2004 Wiley Periodicals, Inc.
\end{abstract}

In the consumer marketing community, customer loyalty has long been regarded as an important goal (Reichheld \& Schefter, 2000). Both marketing academics and professionals have attempted to uncover the most prominent antecedents of customer loyalty. Numerous studies have 
pointed out that two of the more effective means of generating customer loyalty are to delight customers (Lee, Lee, \& Feick, 2001; Oliver, 1999) and to deliver superior value derived from excellent services and quality products (Parasuraman \& Grewal, 2000). In addition, some scholars argue that switching costs, as a key moderating variable, can significantly influence customer loyalty through such determinants as customer satisfaction (Fornell, 1992; Lee et al., 2001; Oliver, 1999) and perceived value (Neal, 1999; Woodruff, 1997).

Only a moderate amount of empirical research has been conducted to examine the relationships among customer loyalty, satisfaction, switching costs, and customer value. No empirical study to date has investigated these constructs in a single framework. The complicated interrelationships among these constructs have not been fully uncovered and understood (T. O. Jones \& Sasser, 1995; Reichheld \& Sasser, 1990). Also, empirical studies from the marketing and economic streams have produced contradictory findings regarding the roles of switching costs in determining customer loyalty (Viard, 2002). Researchers argue that the moderating effect of switching costs on customer loyalty is contingent on situational variables such as the types of businesses, customers, and products, and may not always be significant (C. C. Nielson, 1996). Moreover, although the moderating effect of switching costs on the satisfaction-loyalty relationship has been researched, its impact on the relationship between perceived value and loyalty has essentially been ignored.

The present study attempts to reduce this gap by investigating the interrelationships among the four constructs in the setting of businessto-consumer electronic commerce. The approach employed by the authors involves a consideration of customer satisfaction and perceived value as they interact with switching costs. Specifically, the following three research questions are examined:

- What are the roles of customer satisfaction and perceived value in producing online customer loyalty?

- Is customer satisfaction mediating the effect of customer-perceived value on customer loyalty?

- How do switching costs moderate the effect of customer satisfaction and perceived value on customer loyalty?

This study may contribute to the body of relationship marketing knowledge in several ways. First, it assesses the influence of perceived value on customer loyalty and the mediating role of satisfaction in the value-loyalty relationship. Second, it not only addresses the issue of the ambiguous effect of switching costs on loyalty suggested by previous work but also examines the moderating effect of switching costs on the satisfaction-loyalty and value-loyalty relationships. The overall moderating effects of switching costs upon customer loyalty have been found to be insignificant. However, the results reveal that significant moderating 
effects do exist when the level of customer satisfaction or perceived value is above average. Third, the study establishes a measure of online customer satisfaction. The scale consists of five salient dimensions-customer services, order fulfillment, ease of use, product portfolio, and security/privacy. The study involves an application to a rapidly developed industry, online services, to test the propositions. Researchers have recently called for devoting more efforts to understanding customer behaviors on online services (cf. Yang, Peterson, \& Cai, 2003; Zeithaml, Parasuraman, \& Malhotra, 2002).

\section{CONCEPTUAL FRAMEWORK AND HYPOTHESES}

The conceptual framework guiding this study is presented in Figure 1. Based on the literature review, the authors have generated four hypotheses associated with the model. These hypotheses focus on the interrelationships among customer satisfaction, perceived value, and customer loyalty. In addition, the moderating effects of switching costs on the association of customer loyalty with customer satisfaction and perceived value have been proposed.

\section{Customer Loyalty}

Experience indicates that defining and measuring brand loyalty is extremely difficult. Researchers have used both attitudinal and behavioral measures to define and assess this variable (Oliver, 1999; Zeithaml,

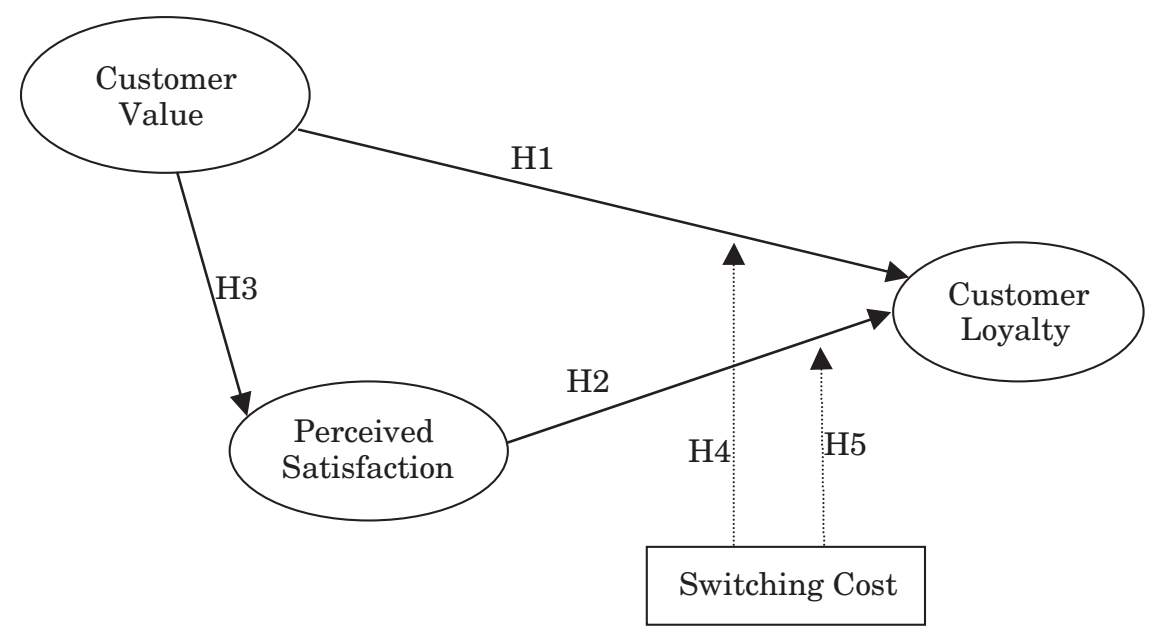

Note: $\quad . \quad \longrightarrow$ Moderating Effect $\longrightarrow$ Direct Effect

Figure 1. Conceptual model. 
2000). From an attitudinal perspective, customer loyalty has been viewed by some researchers as a specific desire to continue a relationship with a service provider (Czepiel \& Gilmore, 1987). From a behavioral view, customer loyalty is defined as repeat patronage, that is, the proportion of times a purchaser chooses the same product or service in a specific category compared to the total number of purchases made by the purchaser in that category (Neal, 1999). The dilemma lies in the fact that intention may not lead to action, and repeated buying behavior may not reflect intentions.

To overcome these drawbacks, Oliver (1999) has proposed four ascending brand-loyalty stages according to the cognition-affect-conation pattern. The first stage is cognitive loyalty. Customers are loyal to a brand based on their information on that brand. The next phase is affective loyalty, which refers to customer liking or positive attitudes toward a brand. The third step is conative loyalty or behavioral intention. This is a deeply held commitment to buy - a "good intention." This desire may result in unrealized action. The last stage is action loyalty, where customers convert intentions into actions. Customers at this stage experience action inertia, coupled with a desire to overcome obstacles to make a purchase. Although action loyalty is ideal, it is difficult to observe and is often equally difficult to measure. As a compromise, most researchers tend to employ the conative or behavioral-intention measure.

Loyalty can be of substantial value to both customers and the firm. Customers are willing to invest their loyalty in business that can deliver superior value relative to the offerings of competitors (Reichheld, 1996). When they are loyal to a firm, consumers may minimize time expended in searching and in locating and evaluating purchase alternatives. Also, customers can avoid the learning process that may consume the time and effort needed to become accustomed to a new vendor.

Customer loyalty is one major driver of success in e-commerce (Reichheld \& Schefter, 2000). Loyal customers often will, over time, bring in substantial revenues and demand less time and attention from the firms they patronize. Many customers are inclined to forgive customer-service mishaps, display decreasing sensitivity to price, and disseminate positive word-of-mouth about the business to others. As a result, customer loyalty can be a major source of sustained growth and profit and a strong asset (E. W. Anderson \& Mittal, 2000).

\section{Customer-Perceived Value}

Perceived value has its root in equity theory, which considers the ratio of the consumer's outcome/input to that of the service provider's outcome/input (Oliver \& DeSarbo, 1988). The equity concept refers to customer evaluation of what is fair, right, or deserved for the perceived cost of the offering (Bolton \& Lemon, 1999). Perceived costs include monetary payments and nonmonetary sacrifices such as time consumption, 
energy consumption, and stress experienced by consumers. In turn, customer-perceived value results from an evaluation of the relative rewards and sacrifices associated with the offering. Customers are inclined to feel equitably treated if they perceive that the ratio of their outcome to inputs is comparable to the ratio of outcome to inputs experienced by the company (Oliver \& DeSarbo, 1988). And customers often measure a company's ratio of outcome to inputs by making comparisons with its competitors' offerings.

Customer value is "the fundamental basis for all marketing activity" (Holbrook, 1994, p. 22). And high value is one primary motivation for customer patronage. In this regard, Sirdeshmukh, Singh, and Sabol (2002) argue that customer value is a superordinate goal and customer loyalty is a subordinate goal, as it is a behavioral intention. According to goal and action identity theories, a superordinate goal is likely to regulate subordinate goals. Thus, customer value regulates "behavioral intentions of loyalty toward the service provider as long as such relational exchanges provide superior value" (Sirdeshmukh et al., 2002, p. 21). Prior empirical research has identified perceived value as a major determinant of customer loyalty in such settings as telephone services (Bolton \& Drew, 1991), airline travel, and retailing services (Sirdeshmukh et al., 2002). Chang and Wildt (1994) report that customer-perceived value has been found to be a major contributor to purchase intention. In light of the preceding discussion and findings, it is proposed that:

H1: Customer loyalty will be positively influenced by customer-perceived value.

\section{The Mediating Role of Customer Satisfaction in the Value-Loyalty Relationship}

Customer satisfaction remains a worthy pursuit among the consumer marketing community (Oliver, 1999). Certainly, customer satisfaction is a critical focus for effective marketing programs. However, the various definitions that appear in the literature tend to diverge from one another (Szymanski \& Henard, 2001). Among the more popular measures, two widely employed approaches are transaction-specific and cumulative or overall satisfaction. The transaction-specific approach defines customer satisfaction as an emotional response by the consumer to the most recent transactional experience with an organization (Oliver, 1993). The associated response occurs at a specific time following consumption, after the choice process has been completed. The affective response varies in intensity depending upon the situational variables that are present. On the other hand, the overall satisfaction perspective views customer satisfaction in a cumulative evaluation fashion that requires summing the satisfaction associated with specific products and various facets of the firm. Some researchers (Cronin \& Taylor, 1992; Parasuraman, Zeithaml, \& Berry, 1988) consider 
overall satisfaction to be primarily a function of perceived service quality. Compared to transactional-specific satisfaction, overall satisfaction reflects customers' cumulative impression of a firm's service performance. In turn, it may serve as a better predictor of customer loyalty.

In the setting of online services, customer satisfaction can be explained by traditional models and two additional conceptual paradigms. The first is the technology adoption model, which proposes that customer intention to adopt a new information technology is primarily determined by the ease of use and the usefulness of the technology (Davis, 1989; Davis, Bagozzi, \& Warshaw, 1989). The Internet is, of course, a relatively new form of information technology. If the ease and usefulness of information and communication through the Internet does not outweigh customer losses occasioned by factors such as impersonal experiences, technical difficulties, and learning effort, then customers may simply revert their patronage back to traditional channels. This being the case, the usefulness and ease of use of Internet transactions play a pivotal role in customer satisfaction with online services.

The second additional conceptual paradigm is the transaction-cost approach (TCA) (Williamson, 1975, 1987). Based on two major assumptions regarding human behavior-bounded rationality and opportunism, TCA focuses on transaction uncertainty, asset specificity, and frequency. Devaraj, Fan, and Kohli (2002) have applied TCA to the Internet channel and found that the efficiency of retail transactions was a function of three aspects of transaction costs. These were perceived ease of use, time efficiency, and price saving. A combination of these two models helps in explaining a large portion of customer satisfaction with Internet-based services (Devaraj et al., 2002).

In this study, customer loyalty was attitudinally measured by customers' behavioral intention to continuously or increasingly conduct business with their present company, and their inclination to recommend the company to other persons. This measure has proven to be useful in previous research (Zeithaml, Berry, \& Parasuraman, 1996). Satisfied customers tend to have a higher usage level of a service than those who are not satisfied (Bolton \& Lemon, 1999; Ram \& Jung, 1991). They are more likely to possess a stronger repurchase intention and to recommend the product/service to their acquaintances (Zeithaml et al., 1996). Numerous studies have revealed that customer satisfaction positively affects loyalty (Bloemer, de Ruyter, \& Wetzels, 1999; Oliver, 1999; Zeithaml et al., 1996). This relationship would seem to be applicable to Internet e-commerce (Reichheld, Markey, \& Hopton, 2000). Therefore, the following hypothesis is advanced:

H2: Customer loyalty will be positively influenced by customer satisfaction.

Customer satisfaction, in turn, is hypothesized to be influenced by perceived value. Perceived value, as it has been defined herein, is the 
ratio of benefits received from providers relative to the costs sacrificed by customers. In essence, it is a variable that reflects the net utility derived from a provider. Customer satisfaction, meanwhile, is defined as an overall positive or negative feeling about the net value of services received from a supplier (Woodruff, 1997). Woodruff (1997) argues that perceived value represents customer cognition of the nature of relational exchanges with their suppliers, and satisfaction reflects customers' overall feeling derived from the perceived value. On the basis of the behavioral model (Fishbein \& Ajzen, 1975), affect is significantly influenced by cognition. There is also empirical evidence that customer-perceived value has a positive effect on customer satisfaction with a supplier (E. W. Anderson \& Mittal, 2000; Walter, Thilo, \& Helfert, 2002). Thus, it is proposed that:

H3: Customer satisfaction will be positively influenced by customerperceived value.

\section{The Moderating Role of Switching Costs}

Switching costs are not only economic in nature (Morgan \& Hunt, 1994) but also can be psychological and emotional (Sharma \& Patterson, 2000). Factors influencing switching costs vary in accordance with the type of products, businesses, and customers. For instance, for technology products, technological interbrand incompatibility can increase switching costs (Marinoso, 2001). In the business-to-business setting, switching costs can be classified as hard assets and soft assets (C. C. Nielson, 1996). And transaction-specific assets (TSAs) are a major source of switching costs (Williamson, 1981). For consumers, switching costs include those that are monetary, behavioral, search, and learning related.

How do switching costs affect customer loyalty? Most previous studies have regarded switching costs as a moderator in the satisfaction-loyalty linkage. When switching costs are substantial or the switching processes especially painful, dissatisfied customers are likely to maintain business relationships with existing service providers and resist the dissolution of the relationship (Jackson, 1985; Port, 1980). As such, false loyal rather than committed loyal groups may exist, including defectors, mercenaries, and hostages (T. O. Jones \& Sasser, 1995). Research has revealed that switching costs can assume a significant moderating effect on customer loyalty through satisfaction. For instance, Lee, Lee, and Feick (2001) have examined the effect of switching costs on the satisfaction and loyalty linkage in the mobile phone service in France and found that switching costs did impose a moderating effect on customer loyalty. Hauser, Simester, and Wernerfelt (1994) have discovered that substantial switching costs reduce customer sensitivity to perceived satisfaction levels. In the same vein, E. 
W. Anderson and Sullivan (1993) have found a negative relationship between switching costs and customer sensitivity to satisfaction levels in the banking industry. Sharma and Patterson (2000) produced findings indicating that in a personal financial-planning service context, switching costs positively moderate the effect of trust and satisfaction on relationship commitment.

Researchers and practitioners, nevertheless, have raised concerns regarding the role of switching costs. Economists normally propose that the impact of switching cost on customer loyalty is relative, conditioned by two opposing forces (Viard, 2002). Although a firm may institute switching costs for its offerings, its competitors frequently erect various strategies and incentives to assist potential customers in overcoming the barriers. For example, numerous online banks and retail brokerage firms afford cash premiums to new customers as an incentive for switching service providers. Some companies furnish free training and demonstrations to familiarize new users with their offerings and thereby diminish learning expenses. In sum, the net effect of switching efforts will depend upon the strength of the switching costs relative to the corresponding benefits made available.

In the Internet market, the materialization of the Internet as a marketplace force has helped reduce searching costs for price and quality information, and comparisons across stores (Bakos, 1997; Lynch \& Ariely, 2000), and has diminished physical travel (J. Nielsen \& Norman, 2000). As competition is just a click away, customers appear to face only minimal barriers to switching product or services providers. Competition is, of course, just a click away in the Internet market, and various antiswitching barriers have been embraced by online firms. Hence, some managers have determined that switching costs may no longer be as effective as they were in the past and be contingent upon different business situations. In other words, the moderating role of switching costs warrants further investigation.

At the same time, virtually no empirical study to date examines the role of switching costs in the relationship between customer-perceived value and loyalty (Woodruff, 1997). Given the high correlation between perceived value and customer satisfaction, it may be assumed that switching costs may impose a similar impact on the relationship between customer-perceived value and loyalty as on the satisfaction-loyalty linkage. Thus, the following hypotheses are proposed:

H4: The higher the level of switching costs, the greater is the likelihood that customer satisfaction will lead to greater customer loyalty.

H5: The higher the level of switching costs, the greater is the likelihood that perceived value will lead to greater customer loyalty. 


\section{RESEARCH DESIGN AND METHOD}

\section{Survey Instrument Development}

Because previous research has not clearly articulated the construct of e-satisfaction, the present study yielded scale items of e-satisfaction through a content analysis of 848 consumer reviews of their online banking experiences. Although the consumer comments (i.e., complaints and compliments) probably do not completely reflect the customer's total experiences with a bank, they do highlight those dimensions of service quality that are of major concern. In the study, all qualified customer reviews were numbered, formatted, and imported to Ethnograph 5.0, a software package designed for content analysis. Based on the first 100 messages, two coders collaborated in developing 68 initial coding words, which made up the primary themes or facets of the overall satisfaction of online services. Two researchers then independently coded the remaining anecdotes. Subsequent discussion identified and resolved all disagreements. The interjudge reliability between the coders calculated by the percentage agreement statistic was $86.6 \%$, which is relatively high according to standards normally employed for statistically assessing interjudge reliability of coding of qualitative data. The content analysis identified 19 dimensions of online customer satisfaction, which were further sorted and regrouped into five dimensions. They were ease of use, customer services, order fulfillment, security/privacy, and product portfolio (for more details, see the Appendix).

Scale items for assessing key constructs, such as customer loyalty, perceived value, and switching costs were adapted from prior studies' validated measures. The respondents were requested to indicate the extent to which they agree or disagree, based on recent online transaction experience, by checking the appropriate response to the questionnaire items regarding the key constructs of the study. For each item, five-point Likert scales anchored by $1=$ strongly disagree and $5=$ strongly agree with $3=$ neutral (neither agree nor disagree) as the midpoint were utilized.

Two types of control variables were employed in the study. The first type was demographic including age, education, sex, and income. The second type was usage - usage frequency and intensity of the Internet and services. Limited research evidence of the effect of demographic variables on loyalty was found. In fact, customer behaviors might be better predictors of loyalty. For instance, Johnson, Moe, Fader, Bellman, and Lohse (2000) point out that CD and book shoppers tend to visit fewer sites as they become more experienced with online shopping.

\section{Pretest}

Five academic experts in relationship marketing were asked to assess the face or content validity of the measurement scales. Subsequently, the ques- 
tionnaire was forwarded by e-mail attachment to 50 online customers selected from two news groups: online financial investment and e-commerce. A total of 14 respondents replied with useful suggestions. Based on their feedback, the questionnaire was further revised and finalized.

\section{Data Collection}

A Web-based survey was employed in the study. A solicitation letter was transmitted by e-mail to 4.000 subjects randomly selected from an e-mailing list provided by an e-mail broker. The e-mail message described the research purpose and invited each receiver to participate in the survey. Sample members who evidenced a willingness to participate were required to click through the URL address provided in the invitation email. A total of $1101 \mathrm{e}$-mails were returned as undeliverable. Thus, the actual undeliverable rate was $27.5 \%$ (1,101 of 4,000), which is similar to the Sheehan and Hoy (2000) study experience (26\%). The responses from 257 participants were forwarded to the leading author via e-mail. Of these, 22 were eliminated because they were incomplete or duplicated (the ISP address of each respondent was checked) responses. Thus, the effective sample size was 235 and the final response rate was $8.1 \%$ (235 of 2,899).

In this study, $80.8 \%$ of the respondents were male; $76.9 \%$ were between the ages of 25 and 54; $68.0 \%$ had earned a bachelor's degree or higher; and $49.4 \%$ had a household income of $\$ 60,000$ or above. The characteristics of these respondents were similar to Internet user profiles gathered in other studies (Kehoe, Pitkow, Sutton, Aggarwal, \& Rogers, 1999; Sheehan $\&$ Hoy, 2000). It was discovered that $74.0 \%$ of respondents were living in the United States and the remaining $26.0 \%$ were from 17 other countries.

As to the computer and Internet usage profile, $90.2 \%$ of the sample had been using personal computers for more than 6 years, $94.1 \%$ reported that they logged onto the Internet at least once a day on average, and $64.6 \%$ spent more than $6 \mathrm{~h}$ per week in browsing Web sites. Table 1 lists means and standard deviations of four constructs and correlations among the 13 variables.

\section{MEASURE VALIDATION}

The J. C. Anderson and Gerbing (1988) two-step approach was employed to evaluate the convergent validity for modeled constructs. In the first phase, exploratory factor analysis was conducted to assess the underlying factor structure of the scale items. The issue of common-method variance was then found to be no problem, in that the first factor failed to comprise a majority of the variance and was no general factor in the unrotated factor structure (Podsakoff \& Organ, 1986). In the second phase, confirmatory factor analysis was performed. It indicated that all factor load- 


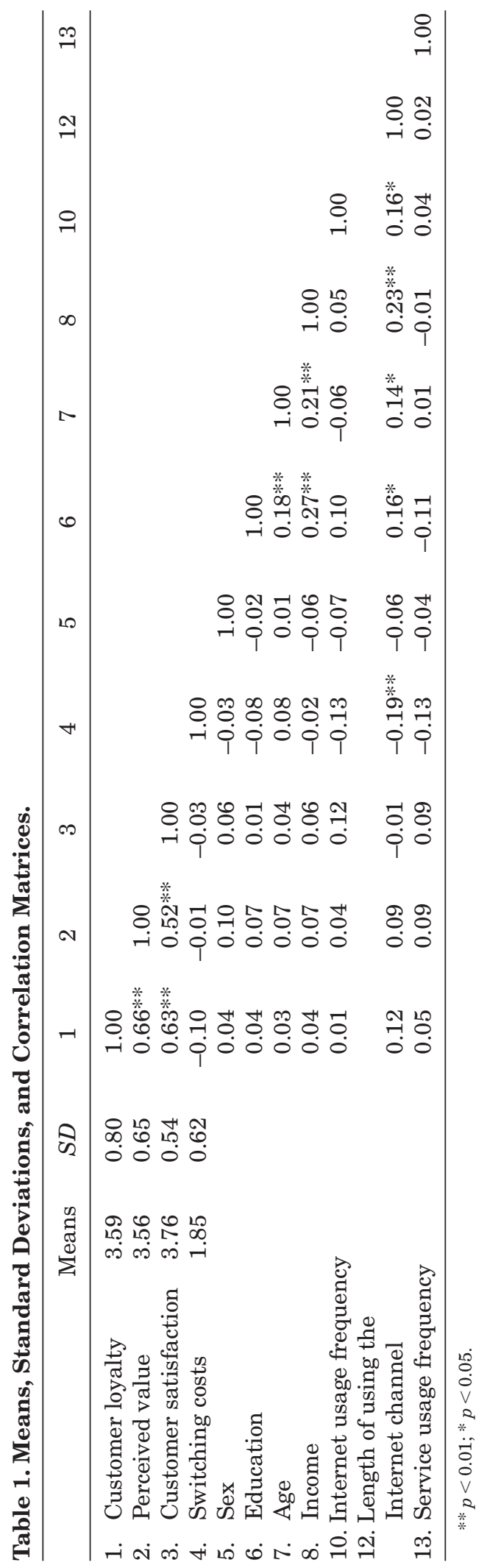


ings were greater than the recommended 0.4 cutoff and were statistically significant (Nunnally \& Bernstein, 1994) (see Table 2). The chisquare statistic was significant. However, the ratio of the chi-square value relative to degrees of freedom (1.60) was less than the cutoff point of 2. Furthermore, the goodness-of-fit index (GFI), adjusted goodness-offit index, normed-fit index, nonnormed-fit index, and comparative-fit index were greater than the recommended 0.9 ; and the root-mean-square error of approximation (RMSEA) was less than 0.08 and not statistically different from 0.05 (Hair, Anderson, Tatham, \& Black, 1995). Therefore, it was reasoned that the model fit the data reasonably well.

The internal validity of the measurement model was examined by calculating the composite reliability and average variance extracted (AVE) (Fornell \& Larcker, 1981). All the composite reliabilities were well above the recommended 0.7 (Nunnally \& Bernstein, 1994). The AVE represents the amount of variance captured by the construct's measures relative to measurement error and the correlations among the latent variables. In this study, the AVE of each measure extracted more than or equal to 50\% of the variance (Bagozzi \& Yi, 1988). The internal validity of the measurement model appears to be adequate.

The discriminant validity of the measures was examined in two ways. First, the AVE was compared with the square of the parameter estimate among the latent variables (Fornell \& Larcker, 1981). The correlation among the indicators of each construct was greater than that between a construct and any other construct. Second, the discriminant validity of each construct was evidenced by each indicator loading higher on the construct of interest than on any other variable.

\section{RESULTS}

\section{The Structural Model}

Simultaneous maximum-likelihood-estimation procedures were utilized in order to examine the hypothesized relationships among perceived value, customer satisfaction, and customer loyalty. Following the recommendation of MacKenzie and Lutz (1989), each latent construct was represented with a single index that is equal to the average score on the construct scale.

Table 3 presents the results of the coefficients and goodness-of-fit statistics. The chi-square statistic was significant; however, the ratio of the chi-square value relative to degree of freedom was less than the cut-off point of $2(2=166.90, \mathrm{df}=89)$. Other fit indices, including GFI (0.92), RMSEA $(0.061,90 \% \mathrm{CI}=0.047-0.075)$, indicate that the proposed model is a reasonable explanation of observed covariance among the study constructs. In addition, the model achieved a satisfactory level of goodness of fit in predicting the variance of customer loyalty (75\%) and customer- 
Table 2. CFA Results of Measures.

\begin{tabular}{lccccc}
\hline Constructs, Sources, and Scale Items & Loading & $t$ value & CR & AVE & $\alpha$ \\
\hline Customer satisfaction (See Appendix) & & & 0.82 & 0.50 & 0.83 \\
1. Customer services & 0.75 & 12.74 & & & \\
2. Order fulfillment & 0.68 & 11.22 & & & \\
3. Ease of use & 0.77 & 13.03 & & & \\
4. Product portfolio & 0.52 & 7.92 & & & \\
5. Security/privacy & 0.69 & 0.69 & & &
\end{tabular}

Perceived value (Adapted from Levesque \& McDougall, 1996)

$\begin{array}{lll}0.88 & 0.56 \quad 0.80\end{array}$

1. Compared to alternative companies, the company offers attractive product/service costs.

$0.58 \quad 9.56$

2. Compared to alternative companies, the company charges me fairly for similar products/services. the company provides more free services.

4. Comparing what I pay to what I might get from other competitive companies, I think the company provided me with good value.

5. Comparing what I pay to what I might get from other competitive companies, I think the company provides me with good value.

Customer loyalty (Adapted from

Mols, 1998).

1. I say positive things about the company to other people.

2. I would recommend the company to those who seek my advice about such matters.

3. I would encourage friends and relatives to use the company.

4. I would post positive messages about the company on some Internet message board. $\quad 0.80$

5. I intend to continue to do business with the present company.

6. I intend to do more business with the present company.

Switching costs (Jones, Mothersbaugh,

\& Beatty, 2000)

1. It takes me a great deal of time and effort to get used to a new company.

2. It costs me too much to switch to another company.

3. In general it would be a hassle switching to another company.

\section{Model fit indices}

$\chi^{2}=166.90(\mathrm{P}=0.00), \mathrm{df}=89, \chi^{2} / \mathrm{df}=1.88$

RMSEA $=0.06$, GFI $=0.92$

$\mathrm{CFI}=0.99, \mathrm{NFI}=0.98, \mathrm{NNFI}=0.98$

Note: $\mathrm{CR}=$ Composite Reliability; $\mathrm{AVE}=$ Average Variance Extracted 
Table 3. Structural Equation Models of Satisfaction, Perceived Value, and Loyalty.

\begin{tabular}{|c|c|c|}
\hline & Coefficient & $t$ value \\
\hline \multicolumn{3}{|l|}{ Dependent Variable: } \\
\hline \multicolumn{3}{|c|}{ Customer Satisfaction } \\
\hline $\mathrm{R}^{2}$ & 0.43 & \\
\hline Perceived Value & 0.65 & $8.65^{* *}$ \\
\hline \multicolumn{3}{|c|}{ Dependent Variable: } \\
\hline \multicolumn{3}{|c|}{ Customer Loyalty } \\
\hline $\mathrm{R}^{2}$ & 0.75 & \\
\hline Perceived Value & 0.60 & $7.17 * *$ \\
\hline Customer Satisfaction & 0.34 & $5.48^{* *}$ \\
\hline \multicolumn{3}{|c|}{ Goodness-of-Fit Statistics } \\
\hline Chi-square (p-value) & $166.90(0.00)$ & \\
\hline $\mathrm{df}$ & 89 & \\
\hline GFI & 0.92 & \\
\hline RMSR & 0.046 & \\
\hline RMSEA & 0.061 & \\
\hline$(90 \% \mathrm{CI})$ & $(0.047,0.075)$ & \\
\hline
\end{tabular}

perceived value (43\%). These indicators demonstrate the fit of the proposed model to the aggregate data. Therefore, further analyses of relationships among the modeled constructs were conducted.

As expected, perceived value and customer satisfaction are two powerful predictors of customer loyalty (the coefficients were 0.60 and 0.34 , respectively). Thus, both $\mathrm{H} 1$ and $\mathrm{H} 2$ are supported. The effect of perceived value on customer satisfaction was also significant. Therefore, H3 is supported. The increased $\mathrm{R} 2$ value $(0.32$, from 0.43 to 0.75$)$ resulting from adding customer satisfaction in the equation is significantly large, indicating that customer satisfaction is a mediating variable in linking customer-perceived value and loyalty (Baron \& Kenny, 1986).

\section{Moderating Effects of Switching Costs on Customer Loyalty}

The fourth and fifth hypotheses posit the moderating effects of switching costs on customer loyalty through satisfaction and perceived value. An analytic procedure for testing moderator effects proposed by Baron and Kenny (1986) was followed. The hierarchical moderated regression analysis was appropriate in order to examine moderating effects (Aiken \& West, 1991; Newsom, Prigerson, Schulz, \& Reynolds, 2001).

Each construct with multi-items was measured through a single index by averaging the item scores for each construct. Thus, the moderator variable, two independent variables, and control variables (i.e., demographic and usage variables) were treated as continuous variables. Initially, a regression of customer loyalty with both control variables and independ- 
ent variables was conducted (see the short model in Table 4). To avoid the multicollinearity issue, the scores of the perceived value variable and two moderators were mean centered. The analysis-of-variance inflation factors confirmed that multicollinearity among the tested variables did not exist. Variance inflation factors are a scaled version of the multiple-correlation coefficients between one variable and the remainder of the independent variables. Because all variance inflation factors were below the cutoff value of 10 , multicollinearity among the variables was not supported (Aiken \& West, 1991). Thus, two product variables that were included as interaction variables in the large models were formed.

The results reported in Table 4 revealed some interesting findings. Although switching costs have a positive impact on customer loyalty, their direct effect on loyalty was insignificant at $\alpha=0.05$ level $(\alpha=0.045$ and 0.06 , respectively). This is consistent with previous studies and arguments (Fornell, 1992; Lee et al., 2001). Additionally, the interactions of switching costs with both customer satisfaction and perceived value imposed negative and negligible influences on customer loyalty $(\alpha=-0.06$ and -0.08 for the financial group; $\alpha=0.31$ and -0.22 for the retailing group). Hence, $\mathrm{H} 4$ and $\mathrm{H} 5$ are not supported.

Table 4. Moderated Regression Analysis of the Effect of Switching Costs on Customer Loyalty (for the Whole Sample).

\begin{tabular}{|c|c|c|c|c|}
\hline & \multicolumn{2}{|c|}{ Short Model } & \multicolumn{2}{|c|}{ Large Model } \\
\hline & $\beta^{\mathrm{a}}$ & $t$ value & $\beta^{\mathrm{a}}$ & $t$ value \\
\hline \multicolumn{5}{|l|}{ Control variables } \\
\hline Sex & -0.07 & -1.23 & -0.06 & -1.09 \\
\hline Education & -0.15 & -0.25 & -0.01 & -0.22 \\
\hline Age & -0.01 & -0.12 & -0.01 & -0.19 \\
\hline Income & 0.01 & 0.12 & 0.01 & 0.11 \\
\hline Years of using the Internet channel & 0.04 & 0.63 & 0.04 & 0.65 \\
\hline Service usage frequency & -0.03 & -0.60 & -0.03 & -0.53 \\
\hline Internet usage frequency & -0.10 & -1.83 & -0.11 & -1.93 \\
\hline \multicolumn{5}{|l|}{ Independent variables } \\
\hline Customer satisfaction & 0.49 & $7.51^{* *}$ & 0.51 & $7.13^{* *}$ \\
\hline Perceived value & 0.46 & $7.22^{* *}$ & 0.48 & $6.73^{* *}$ \\
\hline Switching costs & 0.05 & 0.76 & 0.06 & 1.01 \\
\hline \multicolumn{5}{|l|}{ Interactions } \\
\hline \multicolumn{5}{|l|}{ Switching costs } \\
\hline $\mathrm{X}$ customer satisfaction & & & -0.06 & -0.75 \\
\hline $\mathrm{X}$ perceived value & & & -0.08 & -1.03 \\
\hline $\mathrm{R}^{2}$ & 0.652 & & 0.664 & \\
\hline Adjusted $\mathrm{R}^{2}$ & 0.623 & & 0.629 & \\
\hline F-value & $22.31 * *$ & & $19.23^{* *}$ & \\
\hline Incremental $\mathrm{R}^{2}$ & & & 0.012 & \\
\hline F-value for incremental $R^{2}$ & & & $3.98 *$ & \\
\hline $\mathrm{N}$ & 235 & & 235 & \\
\hline
\end{tabular}

a Standardized value; $* p<0.01 ; * * p<0.001$ 
As a whole, the increased $R^{2} \mathrm{~s}$ in the larger model were marginally significant $(\mathrm{F}=1.95, \alpha<0.05)$. This indicates that including the interaction terms in the main-effects model better explains customer loyalty. In other words, though switching costs do not have moderating effects on the relationships linking both customer satisfaction and perceived value with customer loyalty individually, the aggregated effect of switching costs on customer loyalty still matters.

Given the insignificant moderating effect of switching costs for the whole sample, further analyses were run by dichotomizing the sample according to the levels of customer satisfaction and customer loyalty, respectively. ${ }^{2}$ On the basis of the value of customer satisfaction, two subgroups were formed, with one having a customer-satisfaction value above the mean and another below the mean. Similarly, another two subgroups were formed in terms of the value of customer loyalty. Then, the above-mentioned analytic procedure for testing moderator effects was utilized for each of the four data sets. The results are summarized and reported in Table 5 . The $\mathrm{R}^{2}$ values of the four models were all significant.

The results in Table 5 indicate that switching costs play a significant moderating role in the satisfaction-loyalty relationship only when the level of customer satisfaction is above the mean. The same applies to customer-perceived value. In contrast to previous findings, when the level of customer satisfaction or perceived value is below average, switching costs have no significant moderating impact in the association of customer loyalty with customer satisfaction and perceived value. The results suggest that switching costs could serve as exit barriers only when a firm's services are above average.

\section{DISCUSSION}

\section{Key Drivers of Loyalty}

The findings suggest that customer loyalty can be generated through improving customer satisfaction and offering high product/service value. To satisfy online customers, a firm may focus on five key dimensions identified by the current study. The first is to provide quality customer services. Specifically, company representatives should have the knowledge, including basic technology skills related to e-commerce and the Internet, to answer customer questions. They should understand customer-specific needs, have the capacity to handle problems that arise, and address customer complaints in a friendly manner. Then, it is vital for a firm to perform the service correctly by executing transactions accurately, maintaining customer records without error, and delivering orders promptly.

\footnotetext{
2 The idea was developed on the basis of a suggestion provided by an anonymous reviewer.
} 
Table 5. Moderated Regression Analysis of the Effect of Switching Costs on Customer Loyalty, by Levels of Customer Satisfaction and Perceived Value.

\begin{tabular}{lcccc}
\hline & \multicolumn{2}{c}{ When Perceived Value } & \multicolumn{2}{c}{$\begin{array}{c}\text { When Customer } \\
\text { Satisfaction }\end{array}$} \\
& Above Mean & Below Mean & Above Mean & Below Mean \\
\hline Independent variables & & & & \\
$\quad$ Customer satisfaction & $0.41^{\text {a*** }}$ & $0.54^{* * *}$ & $0.23^{* * *}$ & $0.39^{* * *}$ \\
$\quad \begin{array}{l}\text { Perceived value } \\
\text { Switching costs }\end{array}$ & $0.33^{* * *}$ & $0.24^{* * *}$ & $0.60^{* * *}$ & $0.41^{* * *}$ \\
& 0.09 & 0.07 & -0.03 & -0.01 \\
Interactions & & & & \\
$\quad$ Switching costs & & & & \\
X Customer satisfaction & $0.22^{* *}$ & 0.03 & $0.19^{* *}$ & 0.10 \\
X Perceived value & $0.17^{*}$ & 0.11 & $0.18^{*}$ & 0.02 \\
& & & & \\
$\mathrm{R}^{2}$ & 0.678 & 0.661 & 0.812 & 0.651 \\
Adjusted $\mathrm{R}^{2}$ & 0.459 & 0.436 & 0.507 & 0.424 \\
$F$-value & $18.18^{* * *}$ & $14.55^{* * *}$ & $21.18^{* * *}$ & $14.45^{* * *}$ \\
$\mathrm{~N}$ & 112 & 99 & 108 & 103 \\
\hline
\end{tabular}

Note: Dependent variable: customer loyalty; only the large models are shown; ${ }^{2}$ standardized value; ${ }^{*} p<0.05 ; * * p<0.01 ; * * p<0.001$.

Third, online providers should differentiate their products from other sites by providing an appropriate range and offering features to target customers.

The last two aspects, ease of use and security/privacy, are relevant and essential to the Internet channel. Companies are well advised to design a user-friendly Web site that provides needed menu options and functions. The product information and content should be well-organized and structured, and not difficult to follow. A firm should adopt measures to assure customers that their personal information will be kept confidential and online transactions are safe. Gaining customer trust is essential in the Internet market.

Perceived value is another key driver of customer loyalty and also significantly influences customer satisfaction. As e-commerce has made cost transparency more feasible, total product/service cost, not solely the list price, has become an increasingly important feature for attracting customers. The total cost constitutes both explicit expenses (i.e., product/service price) and implicit expenses such as shipping costs, return costs, coupon usages, discount rewards, and free services. Additionally, firms should provide the product portfolio and value-added free services that are in demand to increase their competitive advantage. Customers make comparisons with both online and off-line competitors. Obtaining desired goods and services is, of course, a primary reason for customers to choose the Internet as an alternative purchasing channel. 


\section{When Do Switching Costs Matter?}

Surprisingly, the study indicates that, on the basis of the aggregate sample, switching costs do not impose a significant moderating effect on the association of customer loyalty with customer satisfaction and perceived value. The addition of the two interaction terms to the main-effect model did better explain customer loyalty. The moderating effect of switching costs is significant only when customer satisfaction or customer-perceived value is higher than the average. These findings differ from those of some previous studies (e.g., Chen \& Hitt, 2002).

The overall lack of a significant moderating effect for switching costs when combined with customer satisfaction and perceived value may be explained, at least in part, by the conflicting roles of switching costs on the one hand, and satisfaction and perceived value on the other. These two sets of variables may act at cross purposes to one another. Switching costs are essentially negative components-elements that online customers could perceive as impediments to effective use of the Internet for shopping. In fact, there is some evidence that switching costs reduce customer satisfaction (Hauser et al., 1994). On the other hand, customer satisfaction and perceived product value are potentially positive contributors to consumer loyalty and their contribution is provided through dimensions such as perceived ease of use, customer services, product portfolio, and security/privacy. The opposing forces created by differing motivations of switching costs and the other two variables could lead to the lack of significant interaction, as predicted by the last two hypotheses.

Further explanation may lie in the nature of e-commerce and the characteristics of online customers. Search engines have made it relatively easy to locate competitive companies and to compare prices. Respondents in the present study indicated that their perceived alternatives of service providers were higher (2.89 out of 5 , which was the highest). Furthermore, because most online consumers are relatively well-educated and have been using computers for years, they may be able to handle many of the marketing hassles involving the issues related to switching barriers. Thus, the overall effect of switching costs on customer loyalty, both directly and indirectly, diminishes and appears not to be significant.

However, when a close examination of subgroups was taken, it reveals an interesting finding that the moderating effects of switching costs do exist when a customer satisfaction or perceived value level is above average. The results can be explained by both cost-benefit theory and prospect theory. Customers tend to employ the net utility, that is, switching benefits minus switching costs, to determine whether they will maintain their relationship with the current service provider. When perceived value or their satisfaction is above average, customers' chance of getting a better service from another provider is not likely to be high. Therefore, the increasing switching costs will reduce their net utility from the switching action, which in turn prevents them from switching. On the contrary, 
when perceived value or satisfaction is below average, customers tend to consider that their losses are larger. According to switching costs, people exhibit loss aversion, i.e., losses loom larger than gains (Kahneman \& Tversky, 1979). As a result, customers tend to overestimate the losses resulting from the existing service provider. Under this situation, the switching costs, no matter how high, are less important compared to their potential losses. In turn, the moderating effect of switching costs appears to be insignificant.

The fact that switching costs serve as a moderator only when the level of customer satisfaction or perceived value is above average has both theoretical and managerial implications. Theoretically, this asymmetric effect of switching costs has not been uncovered by previous studies. Thus, the finding adds incremental knowledge to marketing by providing empirical evidence to a question theoretically unanswered and vital in the rapidly developed electronic market. Managerially, under a competitive business environment, managers should focus on improving customer satisfaction and perceived value to a level that is at least above the industrial standards. Only after that can switching barriers take effect. If firm performance in providing value and satisfaction to customers is below average, any measures to establish switching barriers are likely to be fruitless.

\section{Limitations}

This study is subject to several caveats. First, as was mentioned in the theoretical section, there are tremendous controversies over the definitions of customer satisfaction, perceived value, and loyalty. Although established measures from other studies were adopted and verified, and the e-satisfaction construct was further developed, other measurement versions may yield different results. For instance, customer eloyalty and perceived value may consist of multiple dimensions (Dick \& Basu, 1994; M. A. Jones, Mothersbaugh, \& Beatty, 2002; Oliver, 1999; Sweeney \& Soutar, 2001; Woodruff, 1997). Thus, further studies may be needed as a means of adopting multiple dimensional measures to verify the results.

The second limitation lies in the samples, which were drawn mainly from users of highly competitive online services such as online financial and retailing services. For other industries, such as legal services, management consulting, and medical services, switching costs are higher and may play a greater role.

Finally, this study measured switching costs in a general way. Because of the complicated nature of switching costs (M. A. Jones et al., 2002), future studies may be needed to further explore antecedents of switching costs in the setting of e-commerce. Switching costs may influence customer loyalty through channels other than satisfaction and perceived value (Oliver, 1999). For instance, Oliver (1999) argues that switching bar- 
riers such as social bonding and personal fortitude tend to keep customers loyal to a brand.

\section{CONCLUSION}

The results, evoked from a Web-based survey of online service users, indicate that companies striving for customer loyalty should focus primarily on satisfaction and perceived value. The primary determinants of online satisfaction are customer services, order fulfillment, ease of use, product portfolio, and security/privacy. The moderating effects of switching costs on customer loyalty through satisfaction and perceived value are contingent upon the levels of customer satisfaction and perceived value. Indeed, switching costs serve as a moderator only when a firm achieves above-average performance regarding perceived value and customer satisfaction.

\section{REFERENCES}

Aiken, L. S., \& West, S. G. (1991). Multiple regression: Testing and interpreting interactions. Newbury Park, CA: Sage.

Anderson, E. W., \& Mittal, V. (2000). Strengthening the satisfaction-profit chain. Journal of Service Research, 3, 107-120.

Anderson, E. W., \& Sullivan, M. W. (1993). The antecedents and consequences of customer satisfaction for the firms. Marketing Science, 12, 125-143.

Anderson, J. C., \& Gerbing, D. W. (1988). Structural equation modeling in practice: A review and recommended two-step approach. Psychological Bulletin, 103, 411-423.

Bagozzi, R. P., \& Yi, Y. (1988). On the evaluation of structural equation models. Journal of the Academy of Marketing Science, 16, 74-94.

Bakos, J. Y. (1997). Reducing buyer search costs: Implications for electronic marketplaces. Management Science, 43, 1676-1692.

Baron, R. M., \& Kenny, D. A. (1986). The moderator-mediator variable distinction in social psychological research: Conceptual, strategic, and statistical considerations. Journal of Personality and Social Psychology, 51, 1173-1182.

Bloemer, J., de Ruyter, K., \& Wetzels, M. (1999). Linking perceived service quality and service loyalty: A multi-dimensional perspective. European Journal of Marketing, 33, 1082-1106.

Bolton, R. N., \& Drew, J. H. (1991). A longitudinal analysis of the impact of services changes on customer attitudes. Journal of Marketing, 55, 1-9.

Bolton, R. N., \& Lemon, K. N. (1999). A dynamic model of customers' usage of services: Usage as an antecedent and consequence of satisfaction. Journal of Marketing Research, 36, 171-186.

Chang, T. Z., \& Wildt, A. R. (1994). Price, product information, and purchase intention: An empirical study. Journal of the Academy of Marketing Science, 22, 16-27.

Chen, P. Y., \& Hitt, L. M. (2002). Measuring switching costs and the determinants of customer retention in Internet-enabled businesses: A study of the online brokerage industry. Information Systems Research, 13, 255-274. 
Cronin, J. J., \& Taylor, S. A. (1992). Measuring service quality: A reexamination and extension. Journal of Marketing, 56, 55-68.

Czepiel, J. A., \& Gilmore, R. (1987). Exploring the concept of loyalty in services. In J.A. Czepiel, C. A. Congram, \& J. Shanahan (Eds.), The services challenge: Integrating for competitive advantage (pp. 91-94). Chicago. IL: American Marketing Association.

Davis, F. D. (1989). Perceived usefulness, perceived ease of use, and user acceptance of information technology. MIS Quarterly, 13, 319-340.

Davis, F. D., Bagozzi, R. P., \& Warshaw, P. R. (1989). User acceptance of computer technology: A comparison of two theoretical models. Management Science, 35, 982-1003.

Devaraj, S., Fan, M., \& Kohli, R. (2002). Antecedents of b2c channel satisfaction and preference: Validating e-commerce metrics. Information Systems Research, 13, 316-333.

Dick, A. S., \& Basu, K. (1994). Customer loyalty: Toward an integrated conceptual framework. Journal of Academy of Marketing Science, 22, 99-113.

Fishbein, M., \& Ajzen, I. (1975). Belief, attitude, intention, and behavior: An introduction to theory and research. Reading, MA: Addison-Wesley.

Fornell, C. (1992). A national customer satisfaction barometer: The Swedish experience. Journal of Marketing, 56, 6-21.

Fornell, C., \& Larcker, D. F. (1981). Evaluating structural equation models with unobservable variables and measurement error. Journal of Marketing Research, 18, 39-50.

Hair, J. F., Anderson, R. E., Tatham, R. L., \& Black, W. C. (1995). Multivariate data analysis. Englewood Cliffs, NJ: Prentice Hall.

Hauser, J. R., Simester, D. I., \& Wernerfelt, B. (1994). Customer satisfaction incentives. Marketing Science, 13, 327-350.

Holbrook, M. B. (1994). The nature of customer's value: An axiology of service in consumption experience. In R. T. Rust, \& R. L. Oliver (Eds.), Service quality: New directions in theory and practice (pp. 21-71). Thousand Oaks, CA: Sage Publications.

Jackson, B. B. (1985). Winning and keeping industrial customers: The dynamics of customer relationship. Lexington, MA: Lexington Books.

Johnson, E. J., Moe, W., Fader, P. S., Bellman, S., \& Lohse, J. (2000). On the depth and dynamics of online search behavior. Working paper. The Wharton School, University of Pennsylvania, Philadelphia.

Jones, M. A., Mothersbaugh, D. L., \& Beatty, S. E. (2000). Switching barriers and repurchase intentions in services. Journal of Retailing, 76, 259-274.

Jones, M. A., Mothersbaugh, D. L., \& Beatty, S. E. (2002). Why customers stay: Measuring the underlying dimensions of service switching costs and managing their differential strategic outcomes. Journal of Business Research, 55, 441-450.

Jones, T. O., \& Sasser, W. E. (1995). Why satisfied customer defects. Harvard Business Review, 71, 88-99.

Kahneman, D., \& Tversky, A. (1979). Prospect theory: An analysis of choice under risk. Econometrica, 47, 263-291.

Kehoe, C., Pitkow, J., Sutton, K., Aggarwal, G., \& Rogers, J. D. (1999). Results of GVU's tenth World Wide Web user survey. Available: http://www.cc.gatech.edu/gvu/ user_surveys/survey-1998-10/tenthreport.html

Lee, J., Lee, J., \& Feick, L. (2001). The impact of switching costs on the customer satisfaction-loyalty link: Mobile phone service in France. Journal of Services Marketing, 15, 35-48. 
Levesque, T., \& McDougall, G. H. G. (1996). Determinants of customer satisfaction in retail banking. International Journal of Bank Marketing, 14, 12-20.

Lynch, J. G., \& Ariely, D. (2000). Wine online: Search costs affect competition on price, quality, and distribution. Marketing Science, 19, 83-103.

MacKenzie, S., \& Lutz, R. J. (1989). An empirical examination of the structural antecedents of attitude toward the ad in an advertising pretesting context. Journal of Marketing, 53, 48-65.

Marinoso, B. G. (2001). Technological incompatibility, endogenous switching costs and lock-in. The Journal of Industrial Economics, 44, 281-298.

Mols, N. P. (1998). The behavioral consequences of PC banking. International Journal of Bank Marketing, 16, 195-201.

Morgan, R. M., \& Hunt, S. D. (1994). The commitment-trust theory of relationship marketing. Journal of Marketing, 28, 20-38.

Neal, W. D. (1999). Satisfaction is nice, but value drives loyalty. Marketing Research, 21-23.

Newsom, J. T., Prigerson, H. G., Schulz, R., \& Reynolds III, C. F. (2001). Group differences in prediction in aging research: Statistical, methodological, and conceptual issues (pp. 1-45). Portland, OR: Portland State University.

Nielsen, J., \& Norman, D. A. (2000, February 14). Usability on the Web isn't a luxury. InformationWeek, pp. 65-73.

Nielson, C. C. (1996). An empirical examination of switching cost investments in business-to-business marketing relationships. The Journal of Business and Industrial Marketing, 11, 38-60.

Nunnally, J. C., \& Bernstein, I. H. (1994). Psychometric theory. New York: McGrawHall.

Oliver, R. (1993). Cognitive, affective and attribute bases of the satisfaction response. Journal of Consumer Research, 20, 418-430.

Oliver, R. L. (1999). Whence customer loyalty? Journal of Marketing, 63, 33-44.

Oliver, R. L., \& DeSarbo, W. S. (1988). Response determinants in satisfaction judgments. Journal of Consumer Research, 14, 495-508.

Parasuraman, A., \& Grewal, D. (2000). The impact of technology on the quality-value-loyalty chain: A research agenda. Journal of Academic of Marketing Science, 28, 168-174.

Parasuraman, A., Zeithaml, V. A., \& Berry, L. L. (1988). SERVQUAL: A multipleitem scale for measuring consumer perceptions of service quality. Journal of Retailing, 64, 12-40.

Podsakoff, P. M., \& Organ, D. W. (1986). Self-reports in organizational research: Problems and prospects. Journal of Management, 12, 531-543.

Port, M. E. (1980). Competitive strategy: Techniques for analyzing industries and competitors. New York: Macmillan.

Ram, S., \& Jung, H. S. (1991). How product usage influences customer satisfaction. Marketing Letters, 2, 403-411.

Reichheld, F. F. (1996). Learning from customer defections. Harvard Business Review, 74, 56-67.

Reichheld, F. F., Markey, R. G., \& Hopton, C. (2000). E-customer loyalty-applying the traditional rules of business for online success. European Business Journal, $12,173-179$.

Reichheld, F. F., \& Sasser, W. E. (1990). Zero defections: Quality comes to services. Harvard Business Review, 68, 105-113. 
Reichheld, F. F., \& Schefter, P. (2000). E-loyalty: Your secret weapon on the Web. Harvard Business Review, 78, 105-113.

Sharma, N., \& Patterson, P. (2000). Switching costs, alternative attractiveness and experience as moderators of relationship commitment in professional consumer services. International Journal of Service Industry Management, 11, 470-490.

Sheehan, K. B., \& Hoy, M. G. (2000). Dimensions of privacy concerns among online consumers. Journal of Public Policy and Marketing, 19, 62-73.

Sirdeshmukh, D., Singh, J., \& Sabol, B. (2002). Consumer trust, value, and loyalty in relational exchanges. Journal of Marketing, 66, 15-37.

Sweeney, J. C., \& Soutar, G. N. (2001). Consumer perceived value: The development of a multiple item scale. Journal of Retailing, 77, 203-220.

Szymanski, D. M., \& Henard, D. H. (2001). Customer satisfaction: A meta-analysis of the empirical evidence. Journal of Academic of Marketing Science, 29, 16-35.

Szymanski, D. M., \& Hise, R. T. (2000). E-satisfaction: An initial examination. Journal of Retailing, 76, 309-322.

Viard, V. B. (2002). Do switching costs make markets more or less competitive? The case of 800-number portability. Stanford, CA: Stanford University.

Walter, A., Thilo, A. M., \& Helfert, G. (2002). The impact of satisfaction, trust, and relationship value on commitment: Theoretical considerations and empirical results. Unpublished working paper.

Williamson, O. E. (1975). Markets and hierarchies, analysis and anti-trust implications: A study in the economics of organization. New York: Free Press.

Williamson, O. E. (1981). The economics of organization: The transaction cost approach. American Journal of Sociology, 87, 548-577.

Williamson, O. E. (1987). Transaction cost economics. Journal of Economic Behavior and Organization, 8, 617-625.

Woodruff, R. B. (1997). Customer value: The next source of competitive advantage. Journal of the Academy of Marketing Science, 25, 139-153.

Yang, Z., Peterson, R. T., \& Cai, S. (2003). Service quality dimensions of Internet purchasing: An exploratory analysis. Journal of Services Marketing, 17, 685-698.

Zeithaml, V.A. (2000). Service quality, profitability, and the economic worth of customers: What we know and what we need to learn. Journal of the Academy of Marketing Science, 28, 67-85.

Zeithaml, V.A., Berry, L. L., \& Parasuraman, A. (1996). The behavioral consequences of service quality. Journal of Marketing, 60, 31-46.

Zeithaml, V. A., Parasuraman, A., \& Malhotra, A. (2002). Service quality delivery through Web sites: A critical review of extant knowledge. Journal of the Academic of Marketing Science, 30, 362-375.

The authors thank the two anonymous reviewers for helpful comments on previous versions of this article. The first author gratefully acknowledges a research grant from the City University of Hong Kong (DAG Project No. 7100226).

Correspondence regarding this article should be sent to: Robin T. Peterson, Department of Marketing, New Mexico State University, Las Cruces, NM 88003 (ropeters@nmsu.edu). 


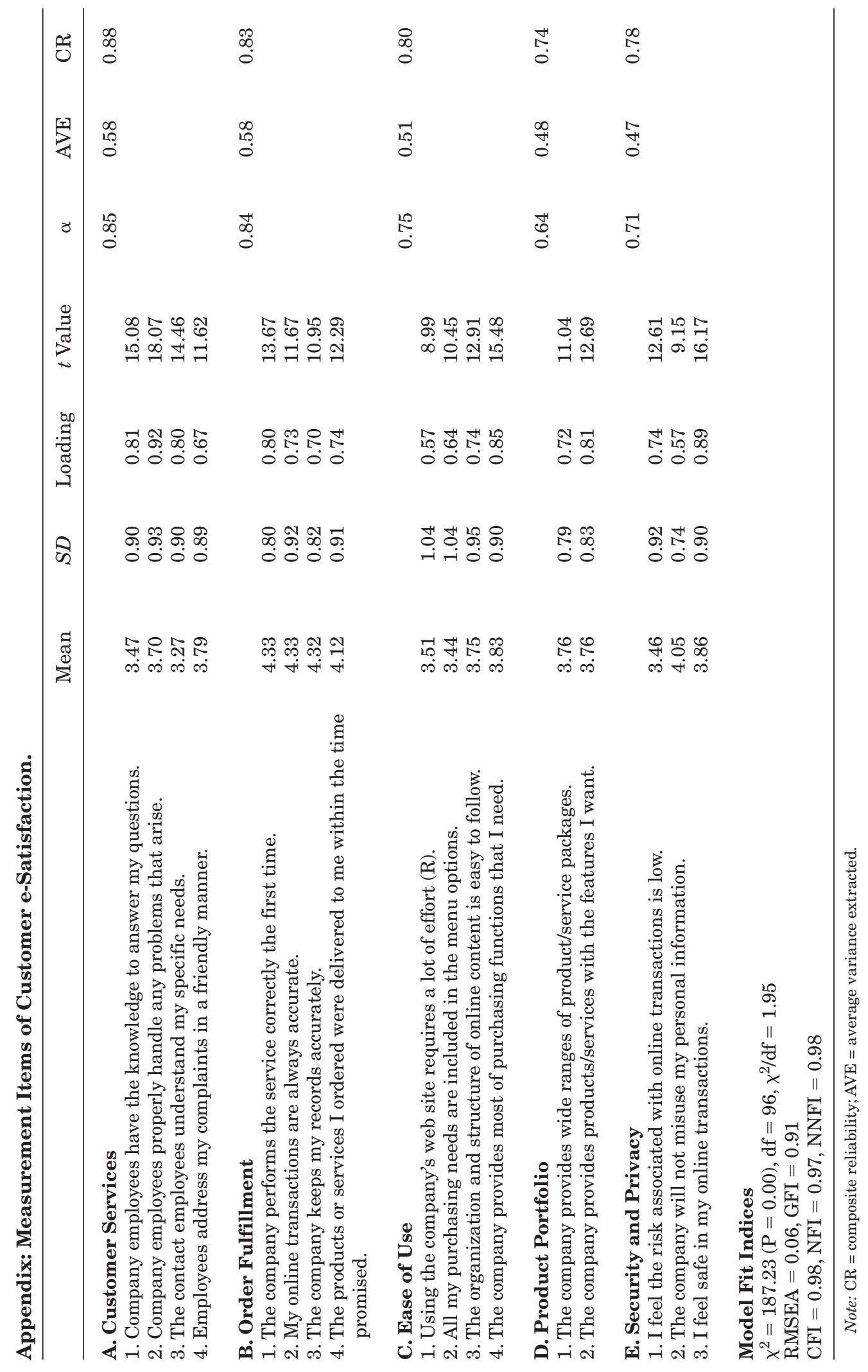

